\title{
FRUIT AND SEED MORPHOLOGY, AND GERMINATION OF Quesnelia quesneliana (BRONGNIART) L.B. SMITH ${ }^{1}$
}

\author{
MATHEUS SILVA CARVALHO ${ }^{2}$, AGNALDO ROBERTO DE JESUS FREITAS $^{2 *}$, DANIEL TEIXEIRA PINHEIRO ${ }^{3}$, \\ DENISE CUNHA FERNANDES DOS SANTOS DIAS ${ }^{3}$
}

\begin{abstract}
Bromeliad Quesnelia quesneliana (Brongniart) L.B. Smith has been reported in the Atlantic Forest, Rainforest, Mesophilic Semideciduous Seasonal Forest, Mangroves and Restingas in the Brazilian southeastern states of Rio de Janeiro and Espírito Santo, but information about their fruit and seed morphology, and germination is limited. The aim of this study was to characterize the external morphology of fruit and seeds, germination rate and post-seminal stages of $Q$. quesneliana. Fruits were collected from Restinga area in the Armação dos Búzios city, Rio de Janeiro, Brazil. The width and length of fruit and seeds (external morphology) were measured, the post-seminal development of the seeds was analyzed and botanical illustrations were made. The indexes t50, uniformity of germination, mean germination time and germination speed coefficient were also calculated. Germination was assessed for 20 days by counting individuals to obtain the post-seminal stages. Ripe $Q$. quesneliana fruits are pyriform, reddish-brown in color, with light spots, 26 $\mathrm{mm}$ long and $10 \mathrm{~mm}$ wide, with an average of 148 seeds per fruit and wrapped in a transparent mucilage. The seeds are $2 \mathrm{~mm}$ long and $1 \mathrm{~mm}$ wide, with epigeal germination, and its seedlings are cryptocotyledonary. The seeds of this species germinate quickly and have no dormancy.
\end{abstract}

Keywords: Bromeliad. Restinga. Post-seminal development.

\section{MORFOLOGIA DE FRUTOS E SEMENTES E GERMINAÇÃO DE Quesnelia quesneliana (BRONGNIART) L.B. SMITH}

\begin{abstract}
RESUMO - Bromélia Quesnelia quesneliana (Brongniart) L.B. Smith foi relatada na Mata Atlântica, Floresta Úmida, Floresta Estacional Semidecidual Mesofílica, Manguezais e Restingas nos estados do sudeste brasileiro do Rio de Janeiro e Espírito Santo, mas informações sobre a morfologia de frutos e sementes e germinação são limitadas. O objetivo neste estudo foi caracterizar a morfologia externa dos frutos e sementes, germinação e estádios pós-seminais de Q. quesneliana. Os frutos foram coletados na área da Restinga, município de Armação dos Búzios, Rio de Janeiro, Brasil. A largura e o comprimento dos frutos e sementes (morfologia externa) foram medidos e o desenvolvimento pós-seminal das sementes foi analisado, como também elaboradas ilustrações botânicas. Foram calculados os índices t50, uniformidade de germinação, tempo médio de germinação e coeficiente de velocidade de germinação. A germinação foi avaliada por 20 dias por meio da contagem de indivíduos para obtenção dos estágios pós-seminais. Os frutos maduros da Q. quesneliana são piriformes, de cor marrom-avermelhada, manchas claras, com $26 \mathrm{~mm}$ de comprimento e $10 \mathrm{~mm}$ de largura na porção mais dilatada, contendo em média 148 sementes, envolvidas por mucilagem transparente. As sementes possuem comprimentos de $2 \mathrm{~mm}$ e $1 \mathrm{~mm}$ de largura, com germinação do tipo epígea e com plântulas do tipo criptocotiledôneas. As sementes dessa espécie germinam rápido e não possuem dormência.
\end{abstract}

Palavras-chave: Bromélia. Restinga. desenvolvimento pós-seminal.

\footnotetext{
${ }^{*}$ Corresponding author

${ }^{1}$ Received for publication in $04 / 28 / 2021$; accepted in 07/30/2021.

Extracted from laboratory research of the first author.

${ }^{2}$ Departament of Soil and Plant Nutrition, Universidade Federal de Viçosa, Viçosa, MG, Brazil; mattheus_cangere@hotmail.com ORCID: 0000-0002-4194-9568, agnaldohu@gmail.com - ORCID: 0000-0003-4545-6485.

${ }^{3}$ Departament of Agronomy, Universidade Federal de Viçosa, Viçosa, MG, Brazil; pinheiroagroufv@gmail.com - ORCID: 0000-00028060-8790,dcdias@ufv.br-ORCID: 0000-0002-0596-2490.
} 


\section{INTRODUCTION}

Restinga is a coastal ecosystem of the Atlantic Forest biome, with high salinity and temperature, intense sun exposure, and sandy soils with low water retention (VALDEMARIN et al., 2019). The biodiversity in Restinga areas consists mainly of Bromeliaceae species, important as habitat for fauna (SOUZA et al., 2016). The genus Quesnelia (Bromeliaceae) has 21 endemic species in the Atlantic Forest distributed in the coast from the Rio de Janeiro to Bahia states (MANTOVANI et al., 2012), such as Quesnelia quesneliana (Brongniart) L.B. Smith, reported in Restinga (SOUZA et al., 2016).

Morphological studies of fruits, seeds, and seedlings are essential mainly for the recognition of species, studies on recovery of degraded areas, and cataloging, once they allow immediate and safe identification of many species (ABUD et al., 2010; PIMENTA et al., 2013; CASTRO et al., 2014; DUARTE et al., 2016; REIS; FEITAS; LEÃO, 2016; BOUBLENZA et al., 2019). Recently, these studies have also been important tools in describing Bromeliads, such as Vriesea minarum (LAVOR et al., 2017), Vriesia sp. (NERI; WENDT; PALMASILVA, 2018), Tillandsia sp. (RAMÍREZ-ROSAS et al., 2020), and others. In this context, the information about morphological characterization of fruits and seeds of Quesnelia quesneliana is scarce. Moreover, it is important to differentiate $Q$. quesneliana from $Q$. arvencis plants that are morphologically similar to close genealogical proximity with the same bootstrap value $(91 \%)$, and differ in the density of crinkling of their floral bracts (FARIA; WENDT; BROWN, 2004; ALMEIDA et al., 2009).

Considering the plant cycle, seed germination is classified as a fundamental step in the establishment of the species in their natural habitat. Seed germination can be defined as the physiological process culminating in the emergence of the embryo from its enclosing coverings. During this process, the absorption of water by the seed (imbibition) activates metabolic processes that subsequently lead to expansion of the embryo and penetration of the radicle through the surrounding tissues (BEWLEY et al., 2013; MARCOS-FILHO, 2016).

Seed vigor can be defined as the sum of those properties that determine the activity and performance of seed lots of acceptable germination in a wide range of environments (ISTA, 2015). According to Finch-Savage and Bassel (2016), seed vigor is a complex trait that is determined during different stages of the mother plant and from seed development to seed imbibition and is greatly influenced by the prevailing environment. In this context, environmental factors such as temperature, water, light and gases directly affect seed germination and vigor (LEROY et al., 2017; ARAÚJO; SILVA, 2018; BHATT et al., 2019a).
When these conditions are unfavorable to the species, many biochemical and ecophysiological aspects of seed germination will be affected and can be evaluated by changes in percentage, speed and frequency of germination, and others (BHATT et al., $2019 \mathrm{~b}$ ). In this context, the evaluation of seed germination and vigor of $Q$. quesneliana could be important to complement the morphology information and assist in the broader knowledge about the species.

Given the above, this work aimed to characterize the fruit and seed morphology of $Q$. quesneliana, as well as analyzing the germination, vigor, and post-seminal stages of this species.

\section{MATERIAL AND METHODS}

The botanical material was collected from dispersed plants in Restinga Forest, municipality of Armação de Búzios, Rio de Janeiro State, Brazil. The plants were identified according to the characteristics described by Almeida et al. (2009) and Souza and Lorenzi (2019). Q. quesneliana seeds were used, each obtained from 20 fruits of different areas. The seeds were extracted and the mucilage was removed by rubbing the seeds with paper towels to prevent fungal proliferation and inhibition of germination (LEROY at al., 2019). Then, the seeds were washed with sodium hypochlorite $(10 \%$ for 30 seconds), dried in the laboratory, stored in paper bags, and kept at room temperature for three days before analysis.

\section{Fruit and seed morphology}

The length and width of twenty $Q$. quesneliana fruits were measured from the average inflorescence portion of this plant with a digital caliper. Seeds were counted manually. Fruit and seeds were weighed on an analytical balance.

Q. quesneliana seeds color and texture were analyzed with a stereoscopic microscope.

\section{Germination}

Eight replications of 50 seeds of $Q$. quesneliana were distributed on two sheets of paper towel, moistened with distilled water (moistened at 2.5 times the weight of the dry paper) in "gerbox" plastic boxes. The boxes were kept in a seed germinator (model 347 CDG, FANEM) with daily alternating temperatures of 20 to $30{ }^{\circ} \mathrm{C}$ and eighthour photoperiod, simulating the natural conditions of the environment.

Germinated seeds were counted daily. Germination was determined according to the emergence of the primary root with minimum length of $2 \mathrm{~mm}$. The germination percentage was calculated by the number of germinated seeds until the 
twentieth day, when the number of germinated seeds stabilized. The germination speed index (GSI) was calculated (Maguire, 1962) by the equation:

$\mathrm{GSI}=\mathrm{N} 1 / \mathrm{DQ}+\mathrm{N} 2 / \mathrm{D} 2+\ldots+\mathrm{Nn} / \mathrm{Dn}$, where: $\mathrm{G} 1, \mathrm{G} 2, \mathrm{Gn}=$ number of seedlings in the first, second and $\mathrm{n}^{\text {th }}$ counts, N1, N2, Nn $=$ number of days from sowing at first, second and $\mathrm{n}^{\text {th }}$ count.

The germination data were processed using the package SeedCalc of the software R (SILVA et al., 2019). The parameters generated by the SeedCalc were t50, uniformity of germination, mean germination time, and germination speed coefficient. These indexes are calculated as described below:

t50: Time required for germination of $50 \%$ of the seeds. $\mathrm{N}$ is the final number of seeds germinated, and $\mathrm{ni}$ and $\mathrm{nj}$ are the total number of seeds germinated in adjacent counts at time ti and tj, respectively, when $n i<\frac{N+1}{2}<n j$ (FAROOQ et al., 2005).

$$
\mathrm{t} 50=\frac{t i+\left[\left(\frac{N}{\left(\frac{100}{50}\right)}\right)-n i\right](t j-t i)}{(n j-n i)}
$$

Uniformity of germination: T90 is the time required for germination of $90 \%$ of the seeds, and $\mathrm{T} 10$ is the time required for germination of $10 \%$ of the seeds (DEMILLY et al., 2014).

Uniformity of germination $=(\mathrm{T} 90-\mathrm{T} 10)$

Mean germination time (MGT): $n_{i}$ is the number of seeds germinated per day (not the accumulated number, but the number corresponding to the $i$-th observation), and $t i$ is the time since the beginning of the germination test up to the $i$-th observation (LABOURIAU, 1983).

$$
\text { MGT }=\sum_{i=1}^{\mathrm{k}} n i t i / \sum_{i=1}^{k} n i
$$

Germination speed coefficient (GSC): $f i$ is the number of newly germinated seeds on day $i$, and $x i$ is the number of days from sowing (NICHOLS; HEYDECKER, 1968).

$$
\mathrm{GSC}=\left(\sum_{i=1}^{k} f i / \sum_{i=1}^{k} f i x i\right) 100
$$

The germination data were analyzed by descriptive statistics, with the presentation of the means.

\section{Post-seminal development}

The phases of post-seminal development were analyzed under a stereomicroscope. Seedlings with a third expanded leaf were observed. The period (days) for the development of germinal structures was defined based on the first day of germination.

\section{Botanical illustrations}

Botanical illustrations of fruit, seed and postseminal development were made every three days, following the average shape of the seeds. After manual illustration, the images received graphic treatment.

\section{RESULTS AND DISCUSSION}

Ripe $Q$. quesneliana fruit is pyriform, reddish -brown in color, with light spots, $26 \pm 0.89 \mathrm{~mm}$ long, and $10 \pm 0.56 \mathrm{~mm}$ wide in the most dilated portion. The average seed per fruit was 148, wrapped in transparent mucilage. The seeds have a spindle-like shape, a more conical micro-portion, rough texture, and no appendages. The length and width of the seeds were $2 \pm 0.51 \mathrm{~mm}$ and $1 \pm 0.15 \mathrm{~mm}$, respectively.

Reduced $Q$. quesneliana fruit and seed size and number is common among species such as Aechmea costantinii (RIOS et al., 2016). Small seed size and length are important for dispersion (NATHAN et al., 2011; MOTATO-VÁSQUEZ; GUGLIOTTA, 2014; MATALLANA et al., 2016) and mucilage attracts dispersing animals (YANG et al., 2012). Although low amount of reserve tissues limits the establishment of Bromeliaceae seedlings, a high number of seeds can contribute to establishment (CHILPA-GALVÁN et al., 2018).

The germination of $Q$. quesneliana seeds is early cryptocotyledonary/epigeal with cotyledon reserve and protrusion of the undeveloped primary root four days after imbibition. Q. quesneliana root hair is developed in hypocotyl between the seventh and ninth day (Figure 1F-G). The eophyll develops from the base of the hypocotyl around the tenth day forming a ring (Figure 1). These seedlings have small casings at the leaf edges and well-developed hairs at the root-shoot transition zone on the third day (Figure 1I).

Epigeal germination and cryptocotyledonous seedlings of $Q$. quesneliana are similar to those reported for Aechmea bambusoides (PAULO; PAULA, 2018). Early germination and a high number of seeds may favor the establishment of this plant, even in competition (MOLIZANE et al., 2013; RIOS et al., 2016).

The first adventitious root of $Q$. quesneliana is hairy and begins to develop just above the stem transition zone on the fifth day. The first leaf, not yet expanded, is surrounded by the sheath of the first (Figure 1K). The second pill-shaped adventitious root develops on the twentieth day (Figure 1L). 
Normal Q. quesneliana seedlings have healthy root development with the complete expansion of the first leaf and initial development of the second
(Figure $1 \mathrm{~J}-\mathrm{K}$ ) and as young after the development of the third leaf (Figure 1L).

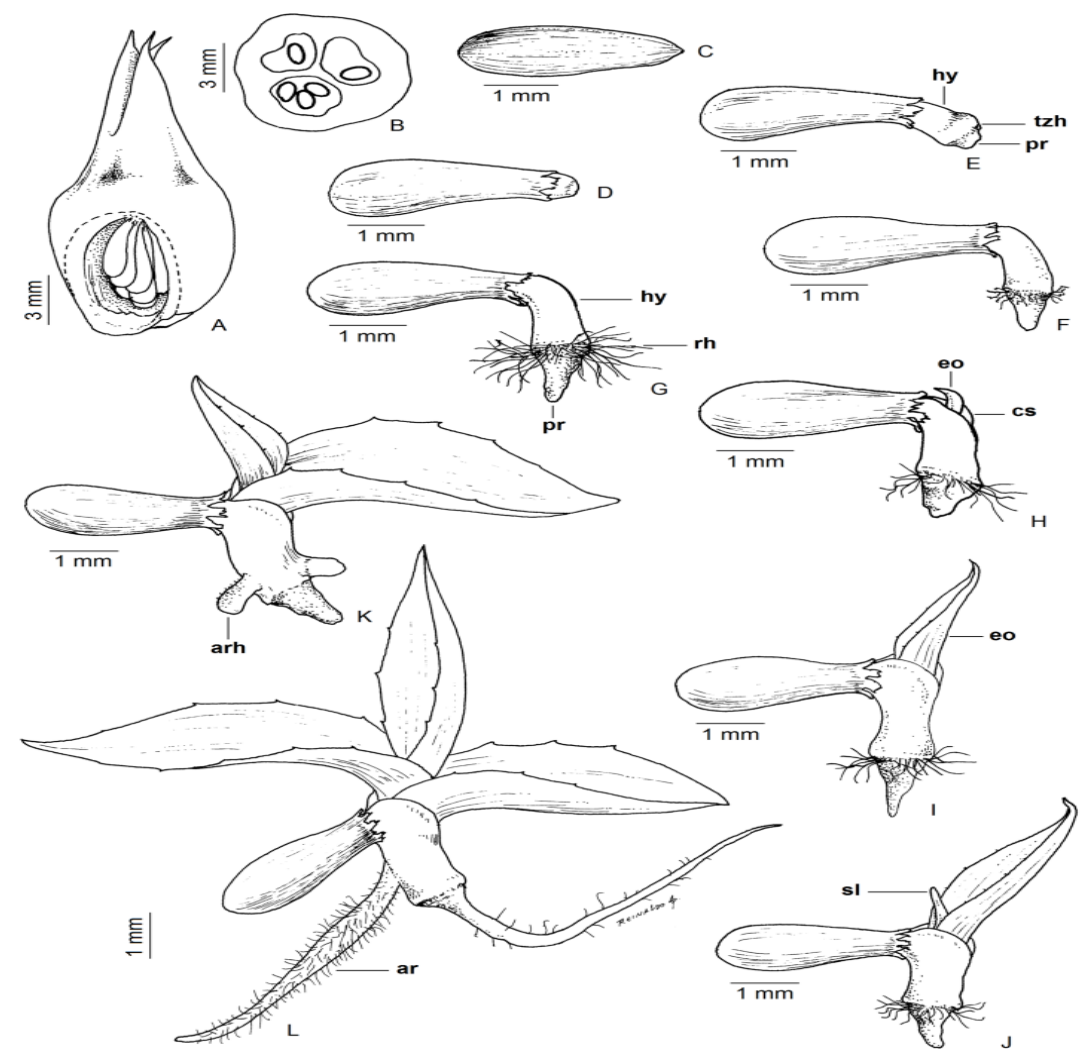

Figure 1. Quesnelia quesneliana fruit, seed and post-seminal development: Fruit with seeds (longitudinal section) (A); Fruit with seeds (cross section) (B); C. Seed; D-G Germination stages; HI. Normal seedling; J-L Young plant; hy: Hypocotyl; tzh: Hairy root-shoot transition zone; pr: primary root; rh: root hairs; cs: Cotyledonary sheath; oil: Eophyll; sl: Secondary leaf; air: Adventitious root; arh: Adventitious root with hair. Illustration: Reinaldo Pinto.

The protrusion of $Q$. quesneliana adventitious roots resembles that of other Bromeliaceae species such as Aechmea blanchetiana, Alcantarea imperialis, and Pitcairnia encholirioides (PEREIRA et al., 2008). The function of elongated primary roots with many root hairs is to absorb water and nutrients in the early stage of seedling development (JIN et al., 2013).

The germination of $Q$. quesneliana seeds started on the third day after sowing, reaching approximately $95 \%$ on the fifteenth day (Figure 2 ).

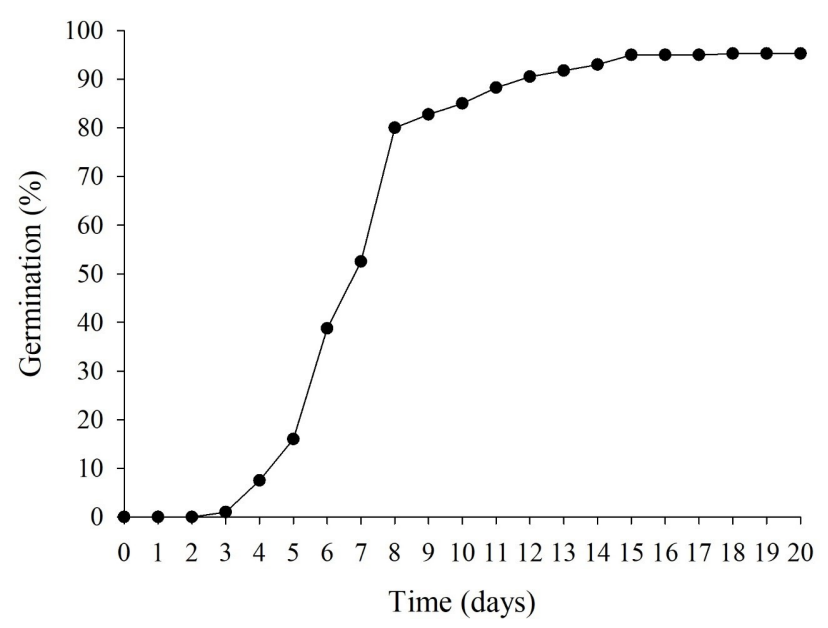

Figure 2. Germination of Quesnelia quesneliana seeds up to the twentieth day. 
According to Lavor et al. (2017), germination rates could be used to determine which of the treatments would guarantee a more efficient reproduction of Bromeliad species. In this context, these authors observed that the germination of Vriesea minarum was initiated in 12-13 days after imbibition, corresponding to the time when the germination of $Q$. quesneliana was already close to $90 \%$. The ungerminated seeds showed a varied aspect, some being empty and others deteriorated (evidencing that this species has no dormancy). Moreover, different from the results observed in the present study, these authors reported low viability of $V$. minarum seeds. In a study that investigated the hybridization potential in Tillandsia species, a significant variation in the germinative potential of these species was reported, which was directly related to interspecific crosses (RAMÍREZ-ROSAS et al., 2020).

The germinative behavior of $Q$. quesneliana can be complemented by the t50, uniformity of germination, mean germination time, and germination speed coefficient (Figure 3).

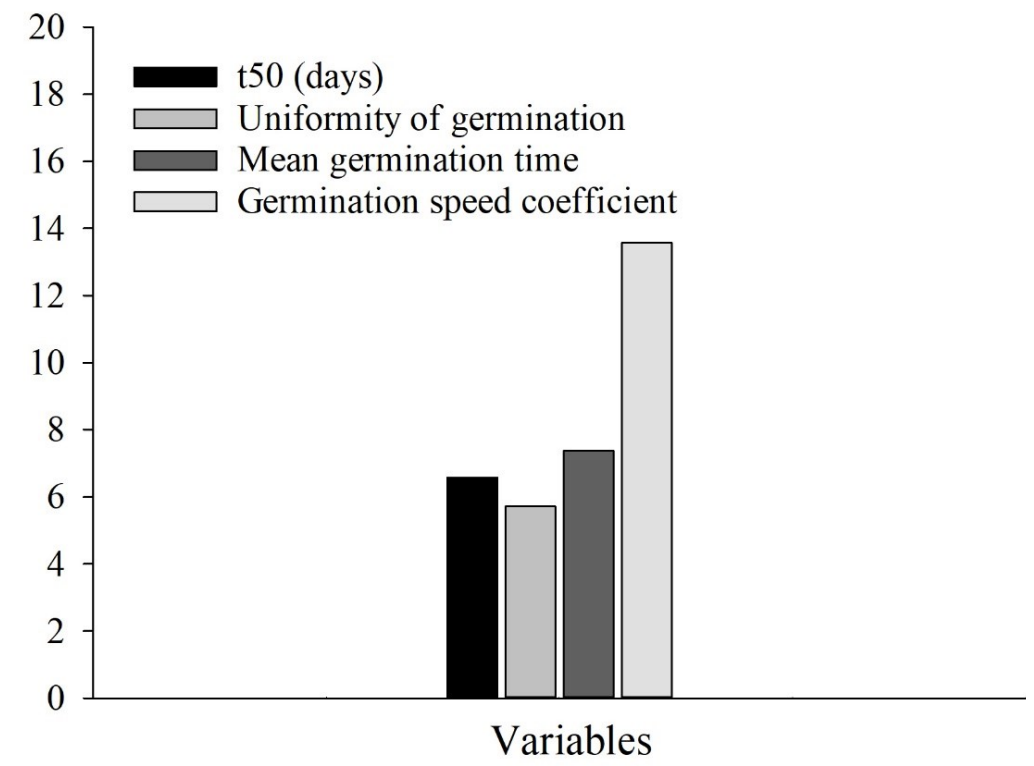

Figure 3. t50, uniformity of germination, mean germination time, and germination speed coefficient of Quesnelia quesneliana seeds.

Recently, these and other similar indexes have been often used to assess the vigor of agricultural species such as Brachiaria grass (MEDEIROS et al., 2020a), melon (MEDEIROS et al., 2020b), mung bean (MACHADO et al., 2020), and others. However, although there was no comparison between different lots, they are unexplored in Bromeliads and may bring future contributions to research with these species. Another important detail to be considered about the observed results, $Q$. quesneliana seeds can be considered as fast germinating, as they have an average time of less than 7 days (Figure 3).

In synthesis, high percentage and speed of germination allow the greater establishment of Bromeliaceae species (LEROY et al., 2019). The results for $Q$. quesneliana were similar to those reported for other Bromeliaceae species, such as Aechmea bambusoides (PAULO; PAULA, 2018). It may be related to genetic factors and greater adaptation of these species in the Restinga, an environment with a high water deficit in the soils (CAMARA et al., 2018).

\section{CONCLUSION}

Ripe Q. quesneliana fruits are pyriform, reddish-brown in color, with light spots, $26 \mathrm{~mm}$ long and $10 \mathrm{~mm}$ wide, with an average of 148 seeds per fruit, and wrapped in a transparent mucilage. The seeds were $2 \mathrm{~mm}$ long and $1 \mathrm{~mm}$ wide, with epigeal germination, and its seedlings are cryptocotyledonary. The seeds of this species germinate quickly and have no dormancy.

\section{ACKNOWLEDGMENTS}

The authors are grateful to the Universidade Federal de Viçosa (UFV), for providing infrastructure and information. This study was funded in part by the Coordenação de Aperfeiçoamento de Pessoal de Nível Superior Brasil (CAPES) - (Funding Code: 001), Conselho Nacional de Desenvolvimento Científico e 
Tecnológico (CNPq), and Fundação de Amparo à Pesquisa do Estado de Minas Gerais (FAPEMIG).

\section{REFERENCES}

ABUD, H. F. et al. Germinação e expressão morfológica de frutos, sementes e plântulas de Pilosocereus pachycladus Ritter. Revista Ciência Agronômica, 41: 468-474. 2010.

ALMEIDA, V. R. et al. Morphological phylogenetics of Quesnelia (Bromeliaceae, Bromelioideae). Systematic Botany, 34: 660-672. 2009.

ARAÚJO, A. V. D.; SILVA, M. A. D. D. Evaluation of the physiological potential of the seeds of Encholirium spectabile Mart. ex Schult. \& Schult. f. Ciência Florestal, 28: 56-66. 2018.

BEWLEY, J. D. et al. Germination. in: BEWLEY, J. D. et al. (Eds.) Seeds: Physiology of Development, Germination and Dormancy. New York, NY: Springer, 2013. v. 3. cap. 4, p. 133-181.

BHATT, A. et al. Influence of temperature, light and salt on the germination of Deverra triradiata seeds. Seed Science and Technology, 47: 25-31. 2019a.

BHATT, A. et al. Effects of storage, mucilage presence, photoperiod, thermoperiod and salinity on germination of Farsetia aegyptia Turra (Brassicaceae) seeds: implications for restoration and seed banks in Arabian Desert. Plant Biosystems-An International Journal Dealing with all Aspects of Plant Biology, 153: 280-287. 2019b.

BOUBLENZA, I. et al. Algerian carob (Ceratonia siliqua L.) populations. Morphological and chemical variability of their fruits and seeds. Scientia Horticulturae, 256: 108537. 2019.

CAMARA, R. et al. Litter dynamics in a forest dune at Restinga da Marambaia, RJ, Brazil. Floresta e Ambiente, 25: 46-56. 2018.

CASTRO, T. C. D. et al. Morphological aspects of fruits, seeds, seedlings and in vivo and in vitro germination of species of the genus Cleome. Journal of Seed Science, 36: 326-335. 2014.

CHILPA-GALVÁN, N. et al. Seed traits favouring dispersal and establishment of six epiphytic Tillandsia (Bromeliaceae) species. Seed Science Research, 28: 349-359. 2018.

DUARTE, M. M. et al. Morphological characterization of fruit, seed and seedling and germination of Hymenaea courbaril L.(Fabaceae)
('Jatobá'). Journal of Seed Science, 38: 204-211. 2016

DEMILLY, D. et al. Digital imaging of seed germination. In: GUPTA, S. D.; IBARAKI, Y. (Eds.). Plant Image Analysis: Fundamentals and Applications. Boca Raton, FL: CRC Press, 2014, v. 1. cap. 7, p. 147-164.

FARIA, A. P. G.; WENDT , T.; BROWN, G. K. Cladistic relationships of Aechmea (Bromeliaceae, Bromelioideae) and allied genera. Annals of the Missouri Botanical Garden, 91: 303-319. 2004.

FAROOQ, M. et al. Thermal hardening: a new seed vigor enhancement tool in rice. Journal of Integrative Plant Biology, 47: 187-193. 2005.

FINCH-SAVAGE, W. E.; BASSEL, G. W. Seed vigour and crop establishment: extending performance beyond adaptation. Journal of Experimental Botany, 67: 567-591. 2016.

ISTA - International Seed Testing Association. International rules for seed testing. Basserdorf, Switzerland: International Seed Testing Association. 2015.

JIN, K. et al. How do roots elongate in a structured soil? Journal of Experimental Botany, 64: 47614777. 2013

LABOURIAU, L. G. Uma nova linha de pesquisa na fisiologia da germinação das sementes. In: CONGRESSO NACIONAL DE BOTÂNICA, 34., 1983, Porto Alegre. Anais... Porto Alegre: SBB, 1983. p. 11-50.

LAVOR, P. et al. Notes on the floral biology, seed morphology and post-seminal development of Vriesea minarum LB Sm., an endangered Bromeliaceae of Southeastern Brazil. Journal of the Bromeliad Society, 66: 87-101. 2017.

LEROY, C. et al. How significant are endophytic fungi in Bromeliad seeds and seedlings? Effects on germination, survival and performance of two epiphytic plant species. Fungal Ecology, 39: 296306. 2019

LEROY, C. et al. The influence of light, substrate and seed origin on the germination and establishment of an ant-garden Bromeliad. Plant Biology, 19: 7078. 2017.

MACHADO, T. P. M. et al. Non-destructive identification of physical damage in mung bean (Vigna radiata L.) seeds by X-ray image analysis. Bioscience Journal, 36: 932-941. 2020. 
MAGUIRE, J. D. Speed of germination aid selection and evaluation for seedling emergence and vigour. Crop Science, 2: 176-177. 1962.

MANTOVANI, A. et al. Leaf anatomy of Quesnelia (Bromeliaceae): implications for the systematics of core bromelioids. Plant Systematics and Evolution, 298: 787-800. 2012.

MARCOS-FILHO, J. Seed physiology of cultivated plant. 1. ed. Londrina, PR: ABRATES, 2016. 616 p.

MATALLANA, G. et al. Post-pollination barriers in an assemblage of Bromeliaceae in southeastern Brazil. Botanical Journal of the Linnean Society, 181: 521-531. 2016.

MEDEIROS, A. D. D. et al. X-ray imaging and digital processing application in non-destructive assessing of melon seed quality. Journal of Seed Science, 42: e202042005. 2020b.

MEDEIROS, A. D. D. et al. High-throughput phenotyping of brachiaria grass seeds using free access tool for analyzing X-ray images. Anais da Academia Brasileira de Ciências, 92: e20190209. 2020a.

MOLIZANE, D. M. et al. Maturação de sementes de Aechmea bromeliifolia (Rudge) Baker e Vriesea paraibica Wawra (Bromeliaceae). Hoehnea, 40: 619625. 2013.

MOTATO-VÁSQUEZ, V.; GUGLiOTTA, A. M. Polypores from an Atlantic rainforest area in southeast Brazil: resupinate species. Brazilian Journal of Botany, 37: 175-185. 2014.

NATHAN, R. et al. Mechanistic models of seed dispersal by wind. Theoretical Ecology, 4: 113-132. 2011.

NERI, J.; WENDT, T.; PALMA-SILVA, C. Natural hybridization and genetic and morphological variation between two epiphytic bromeliads. AoB Plants, 10: plx061, 2018.

NICHOLS, M. A.; HEYDECKER, W. Two approaches to the study of germination data. Proceedings of the International Seed Testing Association, 33: 531-540. 1968.

PAULO, M. L.; PAULA, C. C. Germination and morphology of the post-seminal development of Aechmea bambusoides (Bromeliaceae), a threatened species from the Brazilian flora. Seed Science and Technology, 46: 225-231. 2018.
PEREIRA, A. R. et al. Morfologia de sementes e do desenvolvimento pós-seminal de espécies de Bromeliaceae. Acta Botanica Brasilica, 22: 11501162. 2008.

PIMENTA, A. C. et al. Morphological characterization of fruits, seeds and seedlings of araticum plant (Annona crassiflora MartAnnonaceae). Journal of Seed Science, 35: 524531. 2013.

RAMÍREZ-ROSAS, K. et al. Floral biology and potential hybridization of three sympatric epiphytic bromeliads in Veracruz, Mexico. Plant Species Biology, 35: 197-205. 2020.

REIS, A. R. S.; FREITAS, A. D. D. D.; LEÃO, N. V. M. Morphological aspects of fruits, seeds, and seedlings, and anatomy of seedlings of Apuleia molaris Spruce ex Benth. Journal of Seed Science, 38: 118-128. 2016

RIOS, P. A. F. et al. Seed morphometry and germination of Aechmea costantinii (Mez) LB Sm. (Bromeliaceae). Revista Caatinga, 29: 85-93. 2016.

SILVA, L. J. D. et al. SeedCalc, a new automated R software tool for germination and seedling length data processing. Journal of Seed Science, 41: 250257. 2019

SOUZA, R. C. et al. Role of terrestrial bromeliads in nutrient cycling, Restinga da Marambaia, Brazil. Floresta e Ambiente, 23: 161-169. 2016.

SOUZA, V. C.; LORENZI, H. J. Botânica Sistemática: guia ilustrado para identificação das famílias de fanerógamas nativas e exóticas no Brasil. 4. ed. Nova Odessa, SP: Instituto Plantarum, 2019. $768 \mathrm{p}$

YANG, $\mathrm{X}$. et al. More than just a coating: ecological importance, taxonomic occurrence and phylogenetic relationships of seed coat mucilage. Perspectives in Plant Ecology, Evolution and Systematics, 14: 434 $-442.2012$.

VALDEMARIN, K. S. et al. Two new species of Eugenia (Myrtaceae, Myrtaceae) with fused calyx from the Atlantic coastal forest, Brazil. Phytotaxa, 403: 99-110. 2019. 